\title{
Rose bengal-sensitized nanocrystalline ceria photoanode for dye-sensitized solar cell application
}

\author{
SUHAIL A A R SAYYED ${ }^{1,2}$ , NIYAMAT I BEEDRI ${ }^{1}$, VISHAL S KADAM ${ }^{1}$ \\ and HABIB M PATHAN ${ }^{1, *}$ \\ ${ }^{1}$ Advanced Physics Laboratory, Department of Physics, Savitribai Phule Pune University, Pune 411 007, India \\ ${ }^{2}$ Department of Physics, B.P.H.E. Society's Ahmednagar College, Ahmednagar 414001, India
}

MS received 24 April 2015; accepted 21 March 2016

\begin{abstract}
For efficient charge injection and transportation, wide bandgap nanostructured metal oxide semiconductors with dye adsorption surface and higher electron mobility are essential properties for photoanode in dyesensitized solar cells (DSSCs). $\mathrm{TiO}_{2}$-based DSSCs are well established and so far have demonstrated maximum power conversion efficiency when sensitized with ruthenium-based dyes. Quest for new materials and/or methods is continuous process in scientific investigation, for getting desired comparative results. The conduction band (CB) position of $\mathrm{CeO}_{2}$ photoanode lies below lowest unoccupied molecular orbital level (LUMO) of rose bengal (RB) dye. Due to this, faster electron transfer from LUMO level of $\mathrm{RB}$ dye to $\mathrm{CB}$ of $\mathrm{CeO}_{2}$ is facilitated. Recombination rate of electrons is less in $\mathrm{CeO}_{2}$ photoanode than that of $\mathrm{TiO}_{2}$ photoanode. Hence, the lifetime of electrons is more in $\mathrm{CeO}_{2}$ photoanode. Therefore, we have replaced $\mathrm{TiO}_{2}$ by ceria $\left(\mathrm{CeO}_{2}\right)$ and expensive ruthenium-based dye by a low cost $\mathrm{RB}$ dye. In this study, we have synthesized $\mathrm{CeO}_{2}$ nanoparticles. X-ray diffraction (XRD) analysis confirms the formation of $\mathrm{CeO}_{2}$ with particle size $\sim 7 \mathrm{~nm}$ by Scherrer formula. The bandgap of $2.93 \mathrm{eV}$ is calculated using UV-visible absorption data. The scanning electron microscopy (SEM) images show formation of porous structure of photoanode, which is useful for dye adsorption. The energy dispersive spectroscopy is in confirmation with XRD results, confirming the presence of $\mathrm{Ce}$ and $\mathrm{O}$ in the ratio of 1:2. UV-visible absorption under diffused reflectance spectra of dye-loaded photoanode confirms the successful dye loading. UV-visible transmission spectrum of $\mathrm{CeO}_{2}$ photoanode confirms the transparency of photoanode in visible region. The electrochemical impedance spectroscopy analysis confirms less recombination rate and more electron lifetime in $\mathrm{RB}$-sensitized $\mathrm{CeO}_{2}$ than $\mathrm{TiO}_{2}$ photoanode. We found that $\mathrm{CeO}_{2}$ also showed with considerable difference between dark and light DSSCs performance, when loaded with RB dye. The working mechanism of solar cells with fluorine-doped tin oxide (FTO)/CeO $/ \mathrm{RB}$ dye/carbon-coated FTO is discussed. These solar cells show $V_{\mathrm{OC}} \sim 360 \mathrm{mV}, J_{\mathrm{SC}} \sim 0.25 \mathrm{~mA} \mathrm{~cm} \mathbf{c}^{-2}$ and fill factor $\sim 63 \%$ with efficiency of $0.23 \%$. These results are better as compared to costly ruthenium dye-sensitized $\mathrm{CeO}_{2}$ photoanode.
\end{abstract}

Keywords. Wide bandgap; dye-sensitized solar cells; $\mathrm{CeO}_{2}$; rose bengal dye.

\section{Introduction}

The sun annually supplies about $3 \times 10^{24} \mathrm{~J}$ energy to the earth, which is about 10,000 times more than the global population that currently consumes [1]. The power reaching earth from the sun is $1.37 \mathrm{~kW} \mathrm{~m}^{-2}$, which is free of cost. Since couple of decades, it has become possible to capture the sunlight and turn it into electric power or to generate chemical fuels, such as hydrogen, using advanced technologies. The photovoltaic market is still dominated by conventional semiconductor solar cells, which are expensive. Although photovoltaic technology can provide clean and renewable energy, its high-cost production and installation excludes direct commercial use. It is an urgent requirement to develop cheaper photovoltaic devices with moderate efficiency. DSSC is a promising alternative to conventional semiconductor solar cells, because of low-fabrication cost.

\footnotetext{
*Author for correspondence (pathan@ physics.unipune.ac.in)
}

DSSCs have attracted great interest in recent years due to high performance, simple manufacturing process, high flexibility, semi-transparency, environmental friendliness, high efficiency and low cost etc [2].

Commonly $\mathrm{TiO}_{2}$ is widely considered photoanode material in DSSC application due to non-toxic and chemical stability properties. DSSCs with functioning components of photoanode $\left(\mathrm{TiO}_{2}\right)$, dye molecule (ruthenium-based N3 or N719), electrolyte $\left(\mathrm{I}^{-} / \mathrm{I}_{3}^{-}\right.$as redox electrolyte) and counter electrode (Pt-coated) demonstrated nearly $12 \%$ power conversion efficiency [3]. Metal oxides such as $\mathrm{ZnO}$ [4-7], $\mathrm{Nb}_{2} \mathrm{O}_{5}[8,9], \mathrm{CeO}_{2}$ [10] and $\mathrm{SnO}_{2}$ [11,12] have also been used as alternative photoanode with spherical morphologies in DSSCs. Nair et al [13] studied the effect of $\mathrm{TiO}_{2}$ nanotube length and lateral tubular spacing on photovoltaic properties of back illuminated DSSCs. Cyriac et al [14] developed a new type of solid-state absorber material for DSSCs. Rajkumar et al [15] developed hybrid nanocrystalline $\mathrm{TiO}_{2}$ solar cell with copper phthalocyanine as 
sensitizer and hole transporter. Baviskar et al [16] discussed influence of different processing parameters on chemically grown $\mathrm{ZnO}$ films with low-cost Eosin-Y dye for DSSCs. Great efforts are being focused on the development of DSSCs with semiconductor photoanode as replacement to $\mathrm{TiO}_{2}$ and organic dyes as the sensitizer [17-19]. Researchers have used $\mathrm{CeO}_{2}$ along with $\mathrm{TiO}_{2}$ or $\mathrm{ZnO}$ as photoanode, either to suppress the recombination rate or as a mirror-like coating for absorption of maximum photons by dye [20-26]. There are few reports of directly using $\mathrm{CeO}_{2}$ as photoanode in DSSCs [10]. The $\mathrm{CB}$ position of $\mathrm{CeO}_{2}$ is below the lowest unoccupied molecular orbital (LUMO) level of most of the dyes (also RB dye) $[27,28]$. The recombination rate of electrons is less and hence higher electron lifetime in $\mathrm{CeO}_{2}$ than $\mathrm{TiO}_{2}$ [29]. $\mathrm{CeO}_{2}$ is non-toxic and chemically stable. The conductivity of $\mathrm{CeO}_{2}$ varies from 0.1 to $77 \times 10^{-6} \mathrm{~S} \mathrm{~cm}^{-1}$ depending upon the methods of synthesis, doping and conditions of testing [30,31]. Hence, $\mathrm{CeO}_{2}$ can be considered as a potential candidate for photoanode in DSSCs.

In this study, we have replaced $\mathrm{TiO}_{2}$ by $\mathrm{CeO}_{2}$ and ruthenium-based dye with cost-effective $\mathrm{RB}$ dye. $\mathrm{CeO}_{2}$ nanoparticles were synthesized using simple precipitation method. Initially $\mathrm{CeO}_{2}$ nanocrystalline powder/photoanode was characterized by X-ray diffraction (XRD), scanning electron microscopy (SEM), energy dispersive spectroscopy (EDS), UV-visible spectroscopy (absorption and transmission) and electrochemical impedance spectroscopy (EIS) for its structure, morphology, composition, bandgap and bode plot etc. and then envisaged in DSSCs application. RB dye was characterized using UV-visible absorption spectroscopy. DSSCs were fabricated and photocurrent density-voltage $(J-V)$ characteristics were studied to check the performance.

\section{Experimental}

\subsection{Materials}

Cerium nitrate $\left(\mathrm{Ce}\left(\mathrm{NO}_{3}\right)_{3} \cdot 6 \mathrm{H}_{2} \mathrm{O}\right)$ purchased from HPLC and ammonium hydroxide solution $\left(20 \%, \mathrm{NH}_{4} \mathrm{OH}\right)$ purchased from Thomas Baker were used for synthesis of $\mathrm{CeO}_{2}$ nanoparticles. RB dye purchased from HPLC was used for sensitization of photoanode. Standard iodine solution was used as electrolyte.

\subsection{Synthesis of $\mathrm{CeO}_{2}$ nanoparticles}

The synthesis of $\mathrm{CeO}_{2}$ nanoparticles by precipitation method has been discussed by different researchers [20,32,33]. The nanocrystalline $\mathrm{CeO}_{2}$ powder was prepared using $\mathrm{Ce}\left(\mathrm{NO}_{3}\right)_{3} \cdot 6 \mathrm{H}_{2} \mathrm{O}$ and $\mathrm{NH}_{4} \mathrm{OH}$, where $\mathrm{Ce}\left(\mathrm{NO}_{3}\right)_{3} \cdot 6 \mathrm{H}_{2} \mathrm{O}$ was used as a source of $\mathrm{Ce}^{4+}$ and $\mathrm{NH}_{4} \mathrm{OH}$ was the precipitant.

In a typical synthesis, $0.1 \mathrm{M} \mathrm{Ce}\left(\mathrm{NO}_{3}\right)_{3} \cdot 6 \mathrm{H}_{2} \mathrm{O}$ was prepared in double-distilled water under constant stirring at room temperature, then $20 \mathrm{ml}$ of $20 \% \mathrm{NH}_{4} \mathrm{OH}$ solution was added drop-wise. The final product was kept in an incubator till the water evaporated and the nanaocrystalline
$\mathrm{CeO}_{2}$ powder was collected. This powder was annealed at $450^{\circ} \mathrm{C}$. The crystal structure of the sample was identified using XRD (model no. D-8 Advance Bruker AXS, Germany) equipped with a monochromator $\mathrm{CuK} \alpha$ radiation source $(\lambda=1.54 \AA)$.

\section{$2.3 \mathrm{CeO}_{2}$ electrode fabrication}

To make $\mathrm{CeO}_{2}$ paste, $0.5 \mathrm{~g}$ of the above-prepared $\mathrm{CeO}_{2}$ powder was mixed with $0.4 \mathrm{~g}$ ethyl cellulose, $2.5 \mathrm{~g}$ anhydrous terpineol and $5 \mathrm{ml}$ ethyl alcohol. The mixture was properly mixed using mortar and pestle to form a uniform jelly-like paste, which is then ultra-sonicated for $1 \mathrm{~h}$. Later, this paste was deposited on fluorine-doped tin oxide (FTO) glass using doctor-blade method. After few minutes of drying, electrode was kept for annealing at $450^{\circ} \mathrm{C}$ for $1 \mathrm{~h}$ and then characterized by SEM (JEOL-JSM 6360-A), UV-vis absorption under diffused reflectance spectra and transmission spectra (Jasco, model: V-670).

\subsection{Sensitization of $\mathrm{CeO}_{2}$ electrode}

Annealed $\mathrm{CeO}_{2}$ electrodes were immersed into $0.3 \mathrm{mM} \mathrm{RB}$ dye for $24 \mathrm{~h}$ to adsorb dye. The absorption spectrum of RB dye and dye-loaded photoanode was recorded by UV-vis spectrophotometer in the range of $200-800 \mathrm{~nm}$ to study its optical properties.

\subsection{Preparation of counter electrode}

To prepare counter electrode, the FTO glass was washed with acetone, water and ethanol. After removing contaminants, carbon-coated counter electrode was prepared on the conductive side of the FTO substrate by using mild flame of candle.

\subsection{Fabrication of DSCCs}

To fabricate the DSSCs, few drops of electrolyte solution (iodine) were added to dye-loaded $\mathrm{CeO}_{2}$ photoanode before covering the substrate with counter electrode (carbon-coated FTO). Then, both the photoanode and the counter electrode were clamped together. Later, $J-V$ characteristics of these solar cells were studied.

\section{Results and discussion}

\subsection{XRD analysis}

As shown in figure 1, the XRD pattern of $\mathrm{CeO}_{2}$ consists of eight peaks at $2 \theta=28.6,33.1,47.5,56.4,59.1,68.1,76.8$ and $79.1^{\circ}$ corresponding to (111), (200), (220), (311), (222), (400), (331) and (420) planes of cubic structure of $\mathrm{CeO}_{2}$, respectively, in accordance with Joint Committee on Powder Diffraction Standards (JCPDS no. 81-0792, ICSD\#072155, 


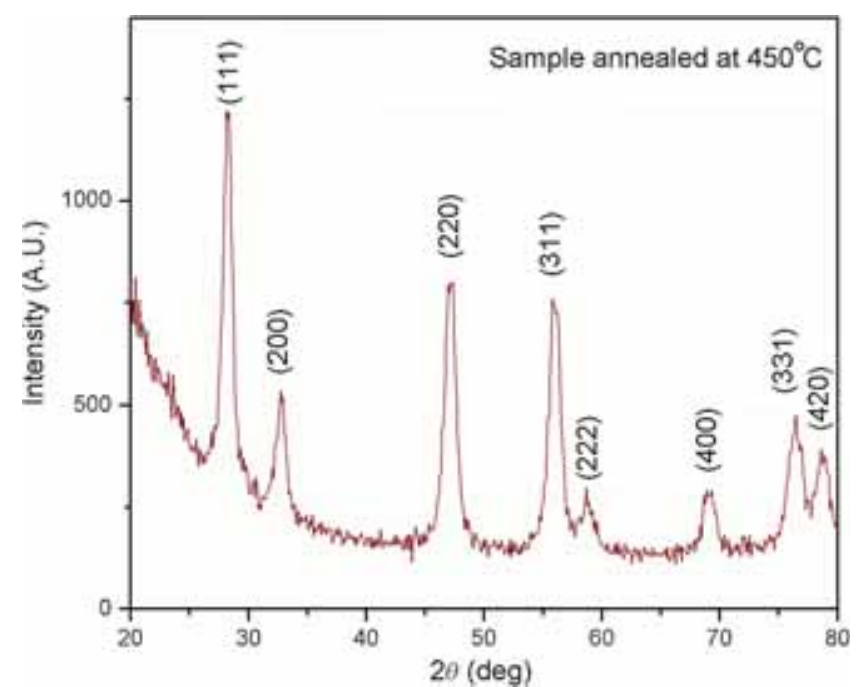

Figure 1. X-ray diffraction pattern of $\mathrm{CeO}_{2}$ powder.

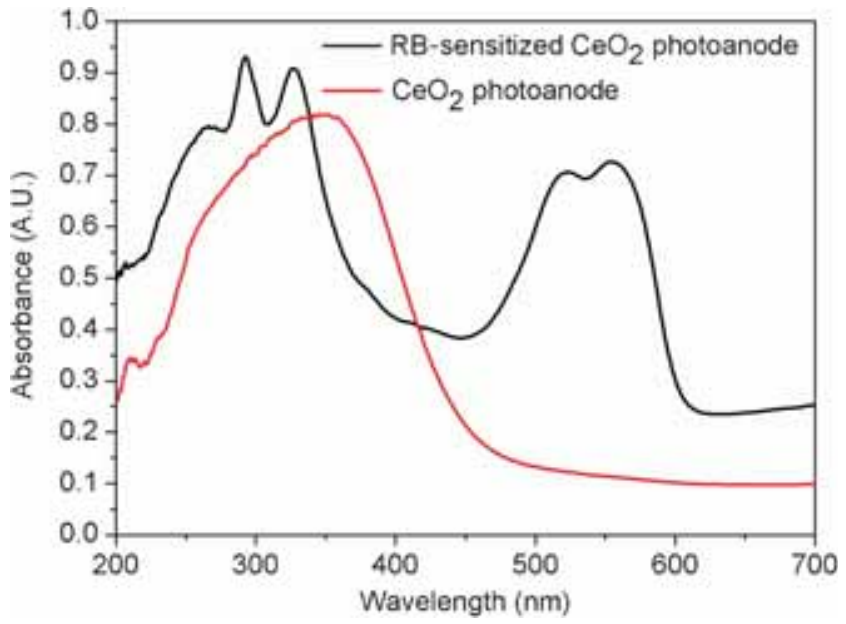

Figure 2. Optical absorption spectra of $\mathrm{CeO}_{2}$ photoanode before and after sensitization with RB dye.

space group: Fm3m (225), unit cell parameters: $a=b=c=$ $5.4124 \AA$ A). No diffraction peaks due to impurities, such as $\mathrm{Ce}(\mathrm{OH})_{2}$, are found in XRD patterns.

The average particle size $(D)$ of $\mathrm{CeO}_{2}$ powder annealed at $450^{\circ} \mathrm{C}$ is estimated by using Debye-Scherrer formula [34].

$$
D=\frac{0.89 \lambda}{\beta \cos \theta},
$$

where $\lambda$ is wavelength of $\mathrm{CuK} \alpha=1.54 \AA, \beta$ the full-width in radians at half-maximum of diffraction peaks and $\theta$ the Bragg's angle of the X-ray pattern at maximum intensity. The estimated particle size is $\sim 7 \mathrm{~nm}$ for the annealed powder at $450^{\circ} \mathrm{C}$.

\subsection{Optical properties of $\mathrm{CeO}_{2}$}

As shown in figure 2, it is observed that the absorption is maximum for as-prepared $\mathrm{CeO}_{2}$ film (annealed at $450^{\circ} \mathrm{C}$ )

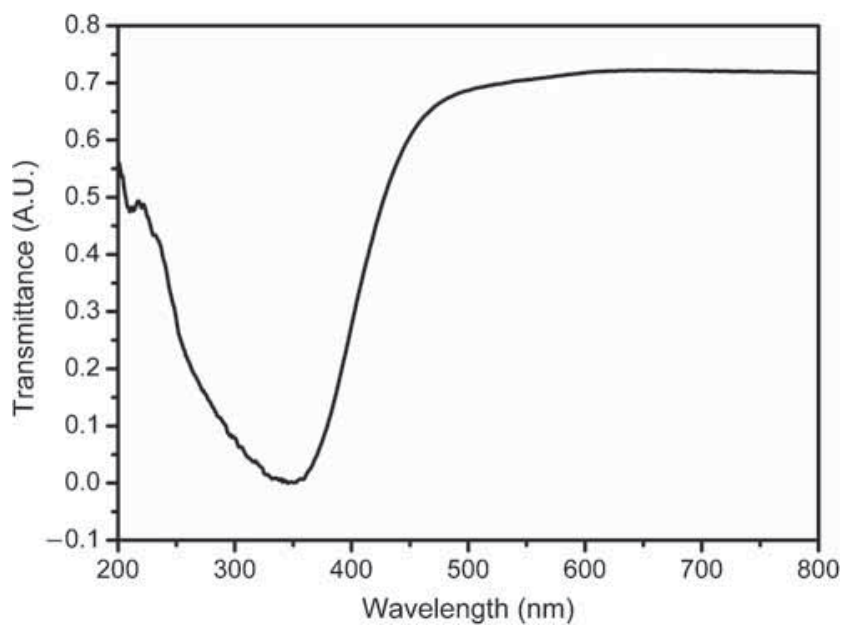

Figure 3. Optical transmittance spectra of $\mathrm{CeO}_{2}$ photoanode.

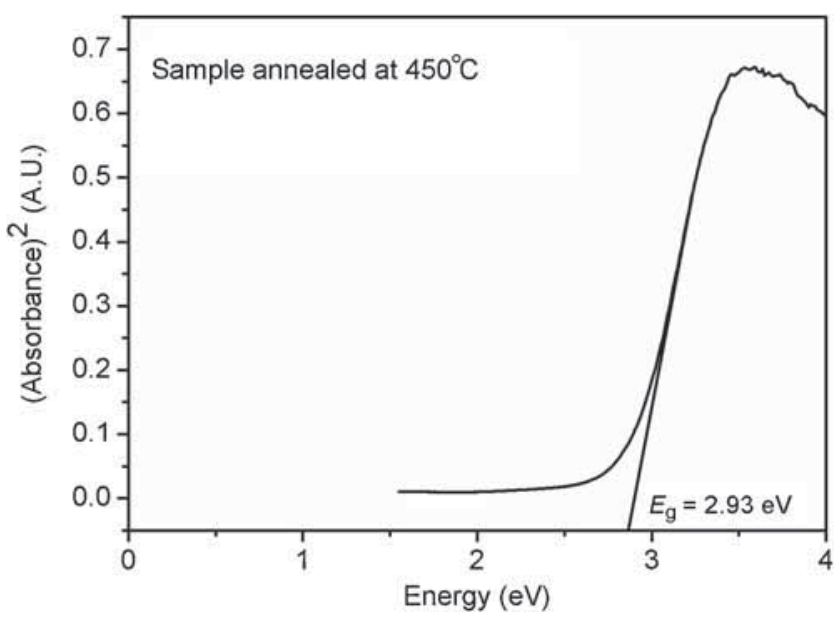

Figure 4. Bandgap energy calculation of $\mathrm{CeO}_{2}$ photoanode.

at $\sim 360 \mathrm{~nm}$. It shows that dye is adsorbed on the $\mathrm{CeO}_{2}$ photoanode. The transmittance $(\% T)$ against wavelength graph, from figure 3 , shows that there is transmission of all the wavelengths in visible range (400-800 nm). Hence complete visible spectrum is available for dye to absorb photons.

The absorption data obtained from UV-vis spectrophotometer are used to calculate the bandgap energy. As shown in figure 4 , the bandgap of $\mathrm{CeO}_{2}$ annealed at $450^{\circ} \mathrm{C}$ is found to be $2.93( \pm 0.02) \mathrm{eV}$. However, the obtained bandgap is lower than the reported bandgap $(3.2 \mathrm{eV})$ of bulk $\mathrm{CeO}_{2}$ [35].

It is well reported that, with decrease in size of crystal, the value of bandgap increases as an effect of quantum confinement [36]. In case of $\mathrm{CeO}_{2}$, the presence of significant fraction of $\mathrm{Ce}$ atoms (in either $3+$ or $4+$ state) on the external surface leads to oxygen vacancies and defects, whose influence on the bandgap overcomes the expected influence of regular quantum size effect $[29,37,38]$. 


\subsection{Optical absorption spectra of $R B$ dye}

Absorption spectrum for the RB dye is shown in figure 5 . The value of $\lambda_{\max }$ is an important parameter as it indicates the possibilities of these molecular systems for considerable use as a functional material in DSSCs. The absorption spectrum of RB dye constitutes four major absorption peaks. The possible transitions are shown in figure 6 . The three peaks are at shorter wavelength region $(265,326$ and $342 \mathrm{~nm})$ may be corresponding to $\pi-\pi^{*}, \sigma-\pi^{*}$ and $\sigma-\sigma^{*}$ transitions. One peak at longer wavelength region $(542 \mathrm{~nm})$ may be due to

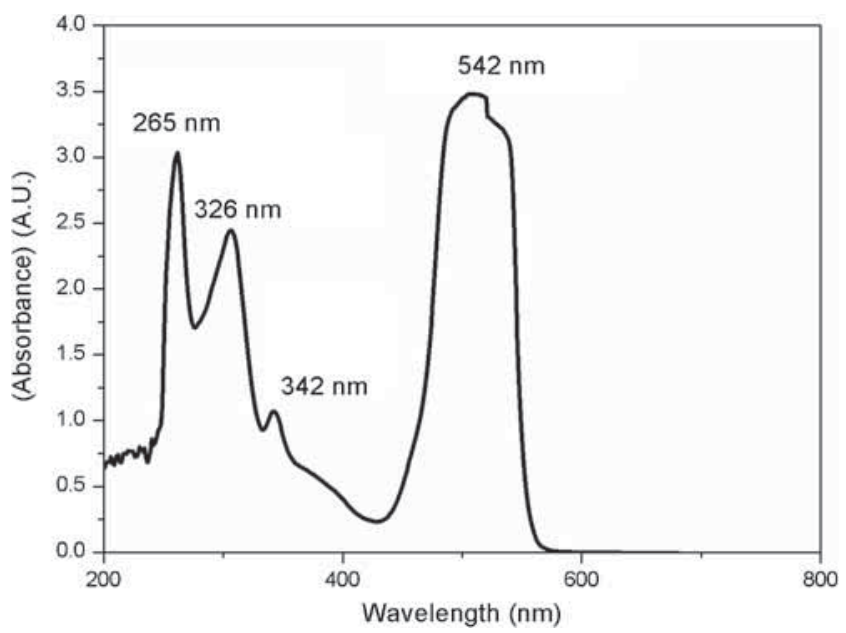

Figure 5. Optical absorption spectrum of RB dye. intra-molecular charge transfer transitions from the donor to acceptor level with highest occupied molecular orbital (HOMO)-LUMO energy levels [39,40].

\subsection{Surface morphology and $\mathrm{EDS}$ of $\mathrm{CeO}_{2}$ film}

The SEM images shown in figure 7 are obtained to study the surface morphology of $\mathrm{CeO}_{2}$ photoanode. The $\mathrm{CeO}_{2}$ possesses network of aggregated spheres-like morphology with pore-size roughly in $60-80 \mathrm{~nm}$ range. The $\mathrm{EDS}$ of $\mathrm{CeO}_{2}$ film is shown in figure 7. The peak heights for $\mathrm{Ce}$ and $\mathrm{O}$ are in the ratio of $1: 2$, confirming the presence of $\mathrm{Ce}$ and $\mathrm{O}$ in the ration of $1: 2$.

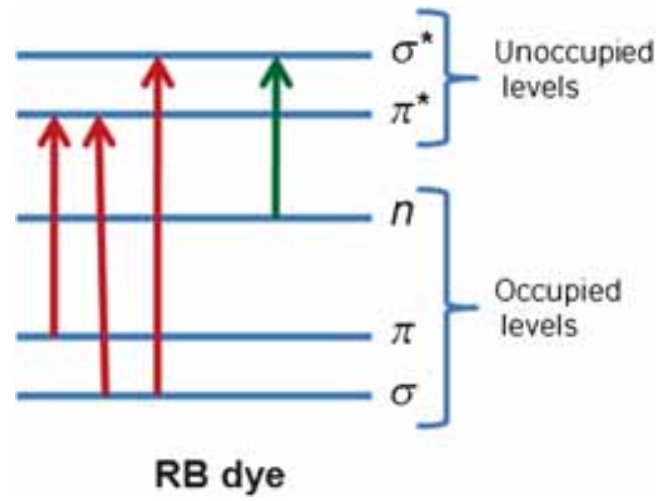

Figure 6. Possible transition mechanisms in RB dye.

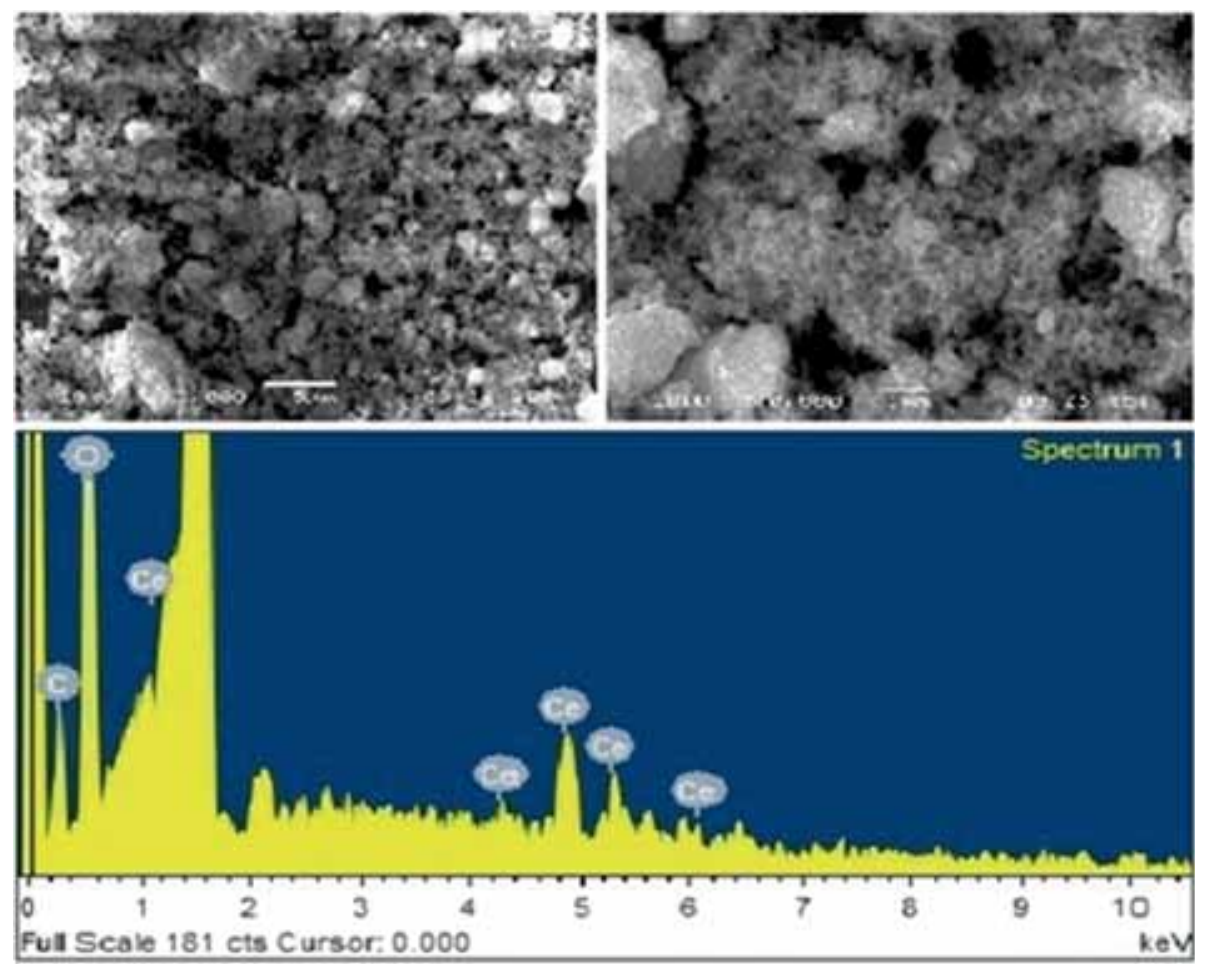

Figure 7. SEM images and $\mathrm{EDS}$ of $\mathrm{CeO}_{2}$ photoanode. 


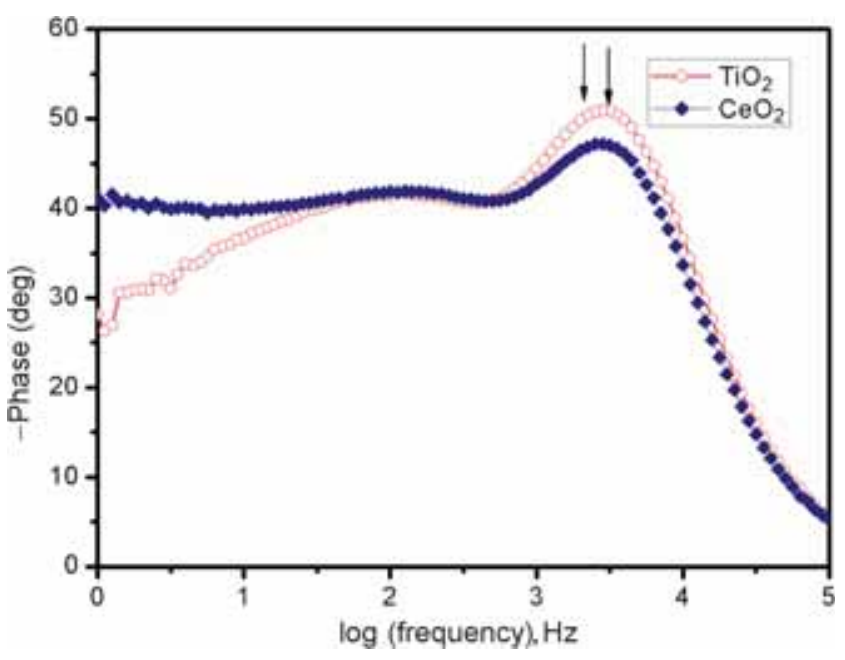

Figure 8. Bode plot for $\mathrm{RB}$-sensitized $\mathrm{TiO}_{2}$ and $\mathrm{CeO}_{2}$ photoanode.

\subsection{EIS analysis}

Figure 8 shows the EIS analysis (Bode plot) for RB-sensitized $\mathrm{CeO}_{2}$ and $\mathrm{TiO}_{2}$ photoanode. For $\mathrm{CeO}_{2}$ photoanode, there is slight negative shift in frequency as compared to $\mathrm{TiO}_{2}$ photoanode. Thus, there is slight increase in lifetime of electrons in $\mathrm{CeO}_{2}$ photoanode, confirming reduction in recombination reactions.

\subsection{Photovoltaic analysis}

Charge transfer process in DSSCs based on RB-sensitized $\mathrm{CeO}_{2}$ photoanode can be explained in similar way as Arote et al [39]. Charge transfer process is shown in figure 9.

When the photons get absorbed by the RB sensitizer, electrons in HOMO level get transferred to excited state, i.e., LUMO level. As observed in figure 9, the CB position of $\mathrm{CeO}_{2}(-0.53 \mathrm{eV})[27,29,37,38,41]$ (vs. normal hydrogen electrode (NHE)) lies below the LUMO level of RB dye $(-0.96 \mathrm{eV})$ [28] (vs. NHE); hence, the electrons in LUMO of $\mathrm{RB}$ dye are injected quickly into the $\mathrm{CB}$ of $\mathrm{CeO}_{2}$ and then finally get transferred to the FTO substrate, where they are utilized for the conduction. The corresponding mechanism of transportation of electrons is represented by equations (2) and (3).

$$
\begin{aligned}
& \mathrm{D}+\mathrm{h} v \rightarrow \mathrm{D}^{*}, \\
& \mathrm{D}^{*} \rightarrow \mathrm{D}^{0}+\mathrm{e}^{-}(\mathrm{CB}),
\end{aligned}
$$

where $\mathrm{D}, \mathrm{D}^{*}$ and $\mathrm{D}^{0}$ correspond to ground state, excited and oxidized molecules of RB dye, respectively. The injected electrons diffuse into $\mathrm{CeO}_{2}$ porous network and transfer through external load towards counter electrode. The oxidized dye is quickly reduced back to its original state by reduced redox species $\left(R_{\mathrm{S}}\right)$ in the electrolyte, which in turn becomes the oxidized redox species $\left(R_{\mathrm{S}}^{0}\right)$.

$$
\mathrm{D}^{0}+R_{\mathrm{S}} \rightarrow \mathrm{D}+R_{\mathrm{s}}^{0}
$$

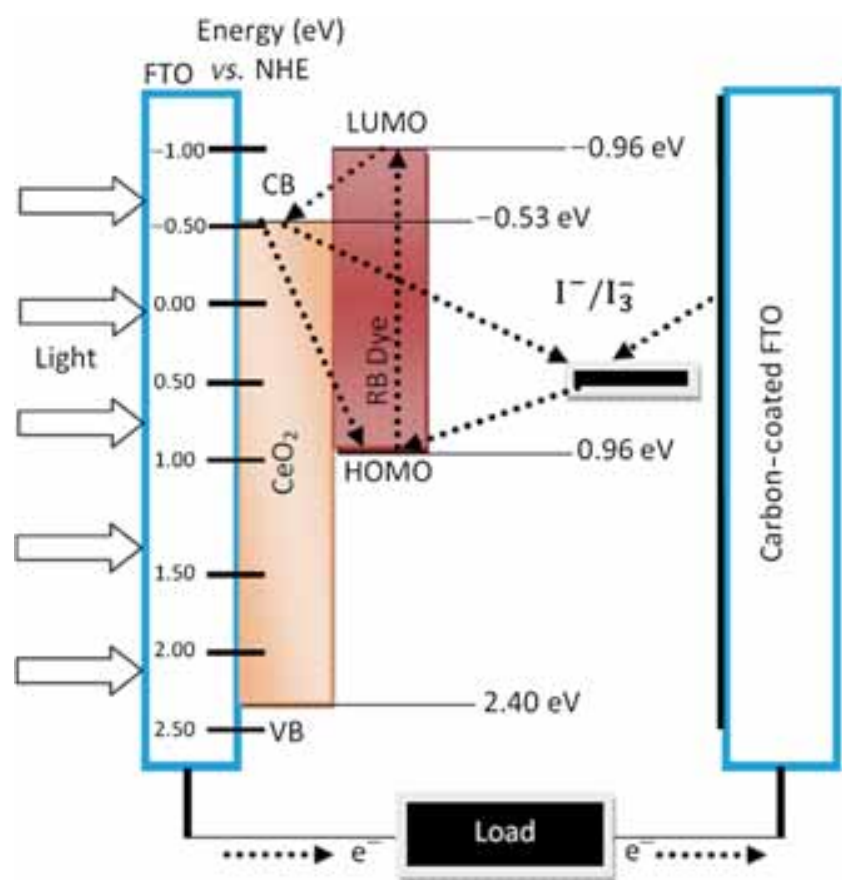

Figure 9. Schematic of processes involved in RB-sensitized $\mathrm{CeO}_{2}$-based DSSCs.

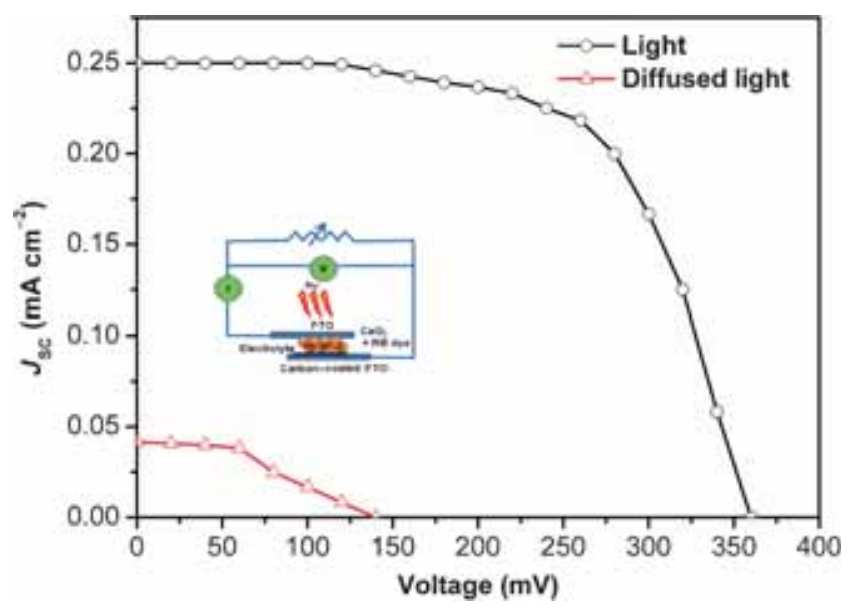

Figure 10. $J-V$ characteristics of DSSCs based on $\mathrm{RB} \mathrm{CeO}_{2}$ photoanode.

where $R_{\mathrm{S}}$ and $R_{\mathrm{S}}^{0}$ are the redox and oxidized species, respectively. This equation is generally called as dye regeneration process. Next, $R_{\mathrm{s}}^{0}$ reduce back to the $R_{\mathrm{S}}$ by accepting electrons from counter electrode, in this way the electrons cycle gets complete.

\subsection{Cell performance analysis}

Figure 10 shows the $J-V$ characteristics of DSSCs based on $\mathrm{CeO}_{2}$ photoanode sensitized with $\mathrm{RB}$ dye. The dye adsorption time was optimized as $24 \mathrm{~h}$. The cell area of $0.12 \mathrm{~cm}^{2}$ was used. The cell performance was observed under light $\left(25 \mathrm{~mW} \mathrm{~cm}{ }^{-2}\right)$ and diffused light $\left(2 \mathrm{~mW} \mathrm{~cm}^{-2}\right)$. The solar 
Table 1. Solar cell parameters.

\begin{tabular}{lcc}
\hline Condition & Light* & Diffused light** \\
\hline$V_{\mathrm{OC}}(\mathrm{mV})$ & 360 & 140 \\
$I_{\mathrm{SC}}(\mathrm{mA})$ & 0.030 & 0.005 \\
$V_{\max }(\mathrm{mV})$ & 260 & 60 \\
$I_{\max }(\mathrm{mA})$ & 0.026 & 0.0046 \\
$J_{\mathrm{SC}}\left(\mathrm{mA} \mathrm{cm}{ }^{-2}\right)$ & 0.25 & 0.0417 \\
Cell area $\left(\mathrm{cm}^{2}\right)$ & 0.12 & 0.12 \\
Efficiency & $0.23 \%$ & $0.12 \%$ \\
Fill factor & $63.07 \%$ & $39.42 \%$ \\
\hline
\end{tabular}

*Light: $25 \mathrm{~mW} \mathrm{~cm}^{-2}$,**diffused light: $2 \mathrm{~mW} \mathrm{~cm}^{-2}$.

cell performance is listed in table 1 . Under light, the solar cells show $V_{\mathrm{oc}}$ and $J_{\mathrm{sc}}$ values of about $360 \mathrm{mV}$ and $0.25 \mathrm{~mA}$ $\mathrm{cm}^{-2}$, respectively, with $0.23 \%$ efficiency and fill factor $(\mathrm{FF})$ $\sim 63 \%$. We observed better performance of the cells as compared to Turkovic and Crnjak [10], in which they noticed $V_{\mathrm{OC}} \sim 60 \mathrm{mV}$ and $J_{\mathrm{SC}} \sim 25 \mathrm{~mA} \mathrm{~cm} \mathrm{~cm}^{-2}$ for costly ruthenium dye-sensitized $\mathrm{CeO}_{2}$ photoanode.

\section{Conclusion}

In this study, the $\mathrm{CeO}_{2}$ nanoparticles were successfully synthesized using chemical precipitation method having nanocrystalline size $\sim 7 \mathrm{~nm}$. The $\mathrm{CeO}_{2}$ films were prepared using doctor-blade method. The SEM shows that the porous structure is useful in DSSCs with bandgap of $2.93 \mathrm{eV}$, confirmed by UV-visible absorption data. The UV-visible absorption curve of RB-sensitized $\mathrm{CeO}_{2}$ photoanode confirms adsorption of dye. The transparency of $\mathrm{CeO}_{2}$ photoanode is confirmed by UV-visible optical transmittance spectra. The recombination rate of electrons is reduced in RB-sensitized $\mathrm{CeO}_{2}$ than RB-sensitized $\mathrm{TiO}_{2}$ photoanode. Hence, there is increase in electron lifetime in RB-sensitized $\mathrm{CeO}_{2}$ photoanode. The photovoltaic performance of cells comprising of $\mathrm{FTO} / \mathrm{CeO}_{2} / \mathrm{RB}$ dye/carbon-coated FTO shows the open circuit voltage $V_{\mathrm{oc}}$ of $360 \mathrm{mV}$ and photocurrent density $J_{\mathrm{SC}}$ of $0.25 \mathrm{~mA} \mathrm{~cm}{ }^{-2}$ with efficiency $\sim 0.23 \%$ and FF $\sim 63 \%$. These results are better as compared with costly ruthenium-sensitized $\mathrm{CeO}_{2}$ photoanode.

\section{Acknowledgements}

We are grateful to the Board of College and University Development (BCUD), Savitribai Phule Pune University, Pune, for financial support through the minor research project OSD/BCUD/360/36. SAS is thankful to the Principal, Dr R J Barnabas, B.P.H.E. Society's Ahmednagar College, Ahmednagar, for kind support and constant motivation.

\section{References}

[1] Lewis N S 2007 Science 315798

[2] O’Regan B and Grätzel M 1991 Nature 353737
[3] Gao F, Wang Y, Shi D, Zhang J, Wang M, Jing X, HumphryBaker R, Wang P, Zakeeruddin S M and Gratzel M 2008 J. Am. Chem. Soc. 13010720

[4] Singh R G, Gautam N, Gautam S K, Kumar V, Kapoor A and Singh F 2013 J. Renew. Sust. Energy 5 033134(1-8)

[5] Khadtare S S, Jadkar S R and Pathan H M 2012 Int. J. Green Nanotechnol. 4528

[6] Khadtare S S, Ware A P, Gawali S S, Jadkar S R, Pingale S S and Pathan H M 2015 RSC Adv. 517647

[7] Kumar V, Singh N, Kumar V, Purohit L P, Kapoor A, Ntwaeaborwa O M and Swart H C 2013 J. Appl. Phys. 114 134506(1-6)

[8] Sayama K, Sugihara H and Arakawa H 1998 Chem. Mater. 10 3825

[9] Lenzmann F, Krueger J, Burnside S, Brooks K, Gra M, Gal D, Ru S and Cahen D 2001 J. Phys. Chem. B 1056347

[10] Turkovic A and Crnjak Z 1997 Sol. Energy Mater. Sol. Cells 45275

[11] Chappel S and Zaban A 2002 Sol. Energy Mater. Sol. Cells 71 141

[12] Shang G, Wu J, Huang M, Lin J, Lan Z, Huang Y and Fan L 2012 J. Phys. Chem. C 11620140

[13] Nair S V, Balakrishnan A, Subramanian K R V, Anu A M, Asha A M and Deepika B 2012 Bull. Mater. Sci. 35489

[14] Cyriac S L, Deepika B, Pillai B, Nair S V and Subramanian K R V 2014 Bull. Mater. Sci. 37685

[15] Sharma Rajkumar G D and Roy M S 2011 Indian J. Pure Appl. Phys. 49557

[16] Baviskar P, Ennaoui A and Sankapal B R 2014 Solar Energy 105445

[17] Sharma G D, Singh S P, Nagarjuna P, Mikroyannidis J A, Ball R J and Kurchania R 2013 J. Renew. Sust. Energy 5043107 $(1-7)$

[18] Hamann T W, Jensen R A, Martinson A B F, Ryswyk H V and Hupp J T 2008 Energy Environ. Sci. 166

[19] Mishra A, Fischer M K R and Bauerle P 2009 Angew. Chem. Int. Ed. 482474

[20] Sayyed S A A R, Beedri N I, Kadam V S and Pathan H M 2016 Appl. Nanosci. 6875

[21] Tripathi M and Chawla P 2014 Ionics 21541

[22] Rai P, Khan R, Ko K J, Lee J H and Yu Y T 2014 J. Mater. Sci.: Mater. Electron 252872

[23] Lira-Cantu M and Krebs F C 2006 Sol. Energy Mater. Sol. Cells 902076

[24] Upadhyay R, Tripathi M, Chawla P and Pandey A 2014 J. Solid State Electrochem. 181889

[25] Hua Y, Yang B, Xu Z, Fengqui T, Max L G Q and Lianzhou W 2012 Chem. Commun. 487386

[26] Roh J, Hwang S H and Jang J 2014 ACS Appl. Mater. Interfaces 619825

[27] Elaziouti A, Laouedj N, Bekka A and Vannier R N 2014 Sciences Technologie A 399

[28] Pradhan B, Batabyal S K and Pal A J 2007 Sol. Energy Mater. Sol. Cells 91769

[29] Corma A, Atienzar P, Garcia H and Chane-Ching J 2004 Nat. Mater. 3394

[30] Fan L, Ma Y, Wang X, Singh M and Zhu B 2014 J. Mater. Chem. A 25399 
[31] Shehata N, Clavel M, Meehan K, Samir E, Soha Gaballah and Salah M 2015 Materials 87663

[32] Godinho M J, Gonçalves R F, Santos L P S, Varela J A, Longo E and Leite E R 2007 Mater. Lett. 611904

[33] Liu Y H, Zuo J C, Ren X F and Yong L 2014 Metalurgija 53463

[34] Azaroff L V 1968 Elements of X-ray crystallography (New York: McGraw-Hill) p 552

[35] Orel Z and Orel B 1994 Phys. Status Solidi B 18633

[36] Brus L E 1984 J. Chem. Phys. 804403
[37] Bueno R M, Martinez-Duart J M, Hernandez-Velez M and Vazquez L 1997 J. Mater. Sci. 321861

[38] Patsalas P, Logothetidis S, Sygellou L and Kennou S 2003 Phys. Rev. B $6 \mathbf{8}$ 035104(1-13)

[39] Arote S, Ingle R, Tabhane V and Pathan H 2014 J. Renew. Sust. Energy 6 013132(1-9)

[40] Singh S P, Roy M S, Thomas K R J, Balaiah S, Bhanuprakash K and Sharma G D 2012 J. Phys. Chem. C 1165941

[41] Liu G, Rodriguez J A, Hrbek J, Dvorak J and Peden C H F 2001 J. Phys. Chem. B 1057762 